\title{
Botanical and Genetic Profiling of Three Rosa Varieties Cultivated in Egypt
}

\author{
Esraa A. Elhawary, Nada M. Mostafa, Rola M. Labib, Abdel Nasser B. Singab \\ Department of Pharmacognosy, Faculty of Pharmacy, Ain Shams University, Cairo 11566, Egypt
}

\begin{abstract}
Genus Rosa belongs to the family Rosaceae and comprises 100 species with a lot of popular ornamental and medicinal plants. Roses are usually utilized as an antioxidant, anti-inflammatory, antimicrobial, sleep aid, and in skin diseases. This study aimed to explore the macro-and micromorphological botanical features of the stems and leaves of three Rosa varieties; Rosa banksiae var. banksaie Ait. (Bankasian Rose) (RBW); R. polyantha Thunb. 'orange fairy' (RPO) and $R$. polyantha Thunb. 'white fairy' (RPW) together with DNA fingerprinting utilizing RAPD-PCR assay and Hierarchal Clustering Analysis (HCA) for the DNA results. The three varieties share the common characters of family Rosaceae viz. compound leaves, colored flowers, and anomocytic stomata while they differ in the color of their flowers, leaflets size, the number of leaflets, and their shapes and types of calcium oxalate. RAPD assay was utilized to differentiate the three varieties genetically where primers OP-P-8, OP-P-10, OP-P-11, OP-P-12, and OP-P-14 showed the highest degree of similarity between RPO and RPW. HCA revealed the closeness of the two polyantha roses forming one cluster in the resulting dendrogram which differentiated them from the Bankasian rose. DNA assay and chemometric analysis were following the botanical profiling.
\end{abstract}

Keywords: Rosa banksiae; Rosa polyantha; Rosaceae; DNA fingerprint; RAPD assay.

*Correspondence Abdel Nasser Badawi Singab; Professor of Pharmacognosy, Chairman of Center for Drug Discovery and Research Development, Faculty of Pharmacy, Ain Shams University, 11566, Cairo, Egypt, Tel.: +20224051120, E-mail: dean@pharma.asu.edu.eg Citation | Elhawary EA, Mostafa NM, Labib RM, Singab AB, 2021. Botanical and Genetic Profiling of Three Rosa Varieties Cultivated in Egypt. Arch Pharm Sci ASU 5(1): 111-127

DOI: $10.21608 /$ aps.2021.73690.1057

Print ISSN: 2356-8380. Online ISSN: 2356-8399.

Received 06 May 2021. Accepted 10 June 2021.

Copyright: ${ }^{\circledR} 2021$ Elhawary et al. This is an open-access article licensed under a Creative Commons Attribution 4.0 International License (CC BY 4.0), which permits unrestricted use, distribution, and reproduction in any medium, provided the original author(s) and source are credited. Published by: Ain Shams University, Faculty of Pharmacy

\section{INTRODUCTION}

Family Rosaceae, commonly known as the Rose family, is one of the important families that play a role as a source of food and ornamental trees and shrubs. The family comprises more than 90 genera and 3500 species widely distributed worldwide except in the Arctic. Rosa is one of the largest genera with 100 species [1]. Leaves are usually alternate, stipulate, and are simple to palmately or pinnately compound. Flowers are characterized by their colorful appearance and heavy blooming nature making them excellent ornamental choices. Roses usually bloom from spring to early summer filling their branches. Flowers are often showy, bisexual, or rarely unisexual, according to each species they appear either solitary or in small clusters from 3 to 7 . Histologically they are bisexual and rarely unisexual, perigynous. The calyx is usually formed of four to five imbricated sepals that are gamosepalous, sometimes epicalyx present. Corolla is formed also of four to five imbricated petals or their multiples, polypetalous, petals unlimited. Androecium consists of an indefinite number of stamens in whorls. The gynoecium appears as several carpels, the ovary is superior $[1,2]$. Wild rose species are characterized by 
extensive variations in their morphology which resulted in complex taxonomy together with interspecies hybridization which occurs naturally or artificially. The new classification of family Rosaceae depends on genetically and/or morphologically-based ways [3].

Rosa banksiae var. banksiae Ait., known as white lady banks or Bankasian rose, is a vigorous climber plant with white blooms that are seen in Spring and early Summer, making it an excellent ornament. The rose is named for Lady Banks, the wife of the botanist Sir Joseph Banks. It is largely cultivated in China especially in Southwest areas [4]. Rosa polyantha Thunb. (syn. Rosa multiflora Thunb.) [5] from the Greek (poly= many and anthos $=$ flowers); Polyantha roses usually bloom heavily and repeatedly around the year, they are short shrub-like and their roses came in many colors as white, orange, pink, red, yellow, and gold. Polyanthas are the backbone flowers of many gardens around the world. Fairy roses represent an important class of polyantha roses and the 1930s witnessed their first introduction as garden roses [6].

Roses are not only utilized for their beautiful shapes and fragrant aroma but they are also rich in a lot of beneficial phytoconstituents such as flavonoids [7], phenolic acids, tannins, anthocyanins, saponins [8], fatty acids, polysaccharides [9], lignans, coumarins, chromones, aurones [10] and volatile constituents [11]. This wide array of components show diverse health benefits for many body ailments mainly as antioxidant [12], anti-inflammatory, analgesic [13], antimicrobial, antidiabetic, antihyperlipidemic, anti-arthritic [14], antiAlzheimer's, antiepileptic, gastro prokinetic, food preservation, wound healing [15] and aromatherapy. The evaluation of the phytoconstituents of different Rosa species was the focus of many articles which tested quantitatively components like flavonoids, phenolics, carotenoids, and anthocyanins [16].

DNA fingerprinting is considered one of the powerful tools for the characterization and authentication of plants. DNA mapping is of great importance especially for plants with complex taxonomy or interrelated species like roses which are difficult to distinguish relying only on their morphological characters [17]. Random Amplified Polymorphic DNA (RAPDPCR) assay is one of the techniques used in DNA fingerprinting, where certain areas of the DNA are amplified randomly using oligonucleotide primer sequences. It is usually used to genetically profile and differentiate plant, animal, and other bio-samples [18]. Earlier reports on roses lack botanical and genetic studies regarding Rosa banksiae var. banksiae Ait. (Bankasian Rose) and Rosa polyantha Thunb. 'orange fairy' and 'white fairy' varieties. Hence, they were chosen for an in-depth botanical and genetic study with the aim of their authentication and differentiation.

\section{MATERIALS AND METHODS}

\subsection{Plant material}

Fresh aerial parts and flowers of Rosa banksiae var. banksiae Ait. (RBW) known as Banksian rose [4] were collected from Merry land Botanical Garden, Cairo, Egypt $\left(30^{\circ} 05^{\prime} 37^{\prime \prime}\right.$ N3 $1^{0} 18$ '51"E), while Rosa polyantha Thunb. 'Orange fairy' (RPO) and Rosa polyantha Thunb. 'white fairy' (RPW) were collected from a private garden, Al-Mariouteya Road, Kirdasah, Giza, Egypt $\left(30^{0} 01^{\prime} 13^{\prime \prime} \quad \mathrm{N} 31^{0} 04^{\prime} 42^{\prime \prime E}\right)$. The samples were collected during March-April 2016 (flowering season) and were authenticated by Eng. Therese Labib, Consultant of Plant Taxonomy at Ministry of Agriculture, El-Orman Botanical Garden, and National Gene Bank, Giza, Egypt. Voucher specimens were kept under codes: (PHG-P-RB 165), (PHG-P-RP 205), and (PHG-P-RP 204) for RBW, RPO, and RPW, respectively at the Herbarium of Pharmacognosy 
Department, Faculty of Pharmacy, Ain Shams University, Cairo, Egypt.

\subsection{Botanical study}

Fresh plant samples of both leaves and stem of the selected Rosa varieties under investigation were fixed in $70 \%$ ethyl alcohol containing $5 \%$ glycerin soon after collection in amber glass separate bottles for each organ. Histological sections were prepared using a manual microtome (American Optical Company model 900) and sections were stained by Safranin and Malachite green. Carl Zeiss optical microscope equipped with Axiocam ICc3 Zeiss camera (Germany) was used in photographing different sections and isolated key elements. Photographs were taken for the leaves and stem sections and isolated elements were taken at both low power (10X) and high power (40X) views. Morphology photographs were taken by Canon-type digital camera.

\subsection{Genetic profiling and DNA fingerprinting}

Fresh leaves and stems of RBW, RPO, and RPW were collected and stored at $-70{ }^{\circ} \mathrm{C}$, freezedried, and ground under liquid nitrogen to a fine powder for DNA extraction. The extraction method followed the method mentioned before [19]. DNA profiling was accomplished at the Agricultural Research Center, Agricultural Genetic Engineering Research Institute.

RAPD-PCR assay: a set of thirteen random decamer oligonucleotide primers were used to amplify the three studied Rosa samples genomic DNA: Operon Technologies Inc., Almeda, California, USA, having the following sequences;

$$
\begin{aligned}
& \text { OP-P-01 (5'-GTAGCACTCC-3'), } \\
& \text { OP-P-02 (5'-TCGGCACGCA-3'), } \\
& \text { OP-P-03 (5'-CTGATACGCC-3'), } \\
& \text { OP-P-04 (5'-GTGTCTCAGG-3'), } \\
& \text { OP-P-06 (5'-GTGGGCTGAC-3'), }
\end{aligned}
$$

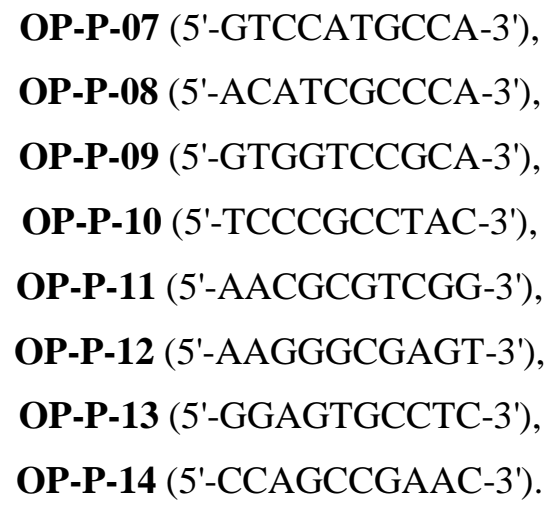

The amplification reaction was carried out in $25 \mu \mathrm{L}$ reaction volume containing $1 \mathrm{X}$ PCR buffer, $1.5 \mathrm{mM} \mathrm{MgCl}_{2}, 0.2 \mathrm{mM}$ dNTPs, $1 \mu \mathrm{M}$ primer $\mathrm{F}, 1 \mu \mathrm{M}$ primer $\mathrm{R}, 1 \mathrm{U}$ Taq DNA polymerase and $25 \mathrm{ng}$ template DNA.

\section{RESULTS}

\subsection{Macromorphological characteristics of $\boldsymbol{R}$. banksiae var. banksiae (RBW) (Fig. 1 A-F)}

RBW is an evergreen climbing rose (Fig. $1 \mathrm{~A})$ growing vigorously to $6 \mathrm{~m}(20 \mathrm{ft}$.) tall. Unlike most roses, it may carry some prickles up to $1 \mathrm{~cm}$ long on shoots (Fig. 1 B). Stems are sympodially branching. The leaves are compound imparipinnate (Fig. 1 C), with three leaflets in young leaves (Fig. 1 D) and five leaflets in older ones (Fig. 1 E) with the largest leaflet at the top in both types. Leaflets are lanceolate in shape for young leaves and ovate in shape for old leaves. Leaflets are 3-4 cm long for young and $2-4 \mathrm{~cm}$ long for old and $1-1.5 \mathrm{~cm}$ in width with serrate margin and asymmetric lamina base. Flowers are white in color, solitary or in clusters of three, showy and filling the branches with mild odor. They are small, $3-5 \mathrm{~cm}$ in diameter, blooms from late March to May (Fig. 1 F).

\subsubsection{The Stem (Fig. 1 B \& C)}

Stem color varies from pale green in young to brown in older branches; carrying alternate compound leaves (Fig. 1 B). Stem branches are cylindrical in shape about $0.5 \mathrm{~cm}$ in diameter, 
having smooth surfaces (Fig. 1 C). They break easily exposing projecting fibers and pale yellow surfaces. The internodes are $4-6 \mathrm{~cm}$ in length. Stems are odorless and bitter in taste.

\subsubsection{The Leaf (Fig. 1 D \& E)}

Leaves are compound, imparipinnate, petiolate, and stipulate, with three to five leaflets. Young leaves (Fig. 1 D) show three leaflets that are lanceolate in shape with terminal ovatelanceolate one while old leaves (Fig. 1 E) carry five leaflets that are ovate in shape with an apical larger one. Leaflets are green showing a darker upper surface and covered with leathery cuticle. The leaf petiole is grooved on the upper surface. They possess an acuminate apex, with terminal short apiculus, serrate margin, and lamina base that is asymmetric. The midrib is prominent on the lower surface and depressed on the upper surface. The leaflet has pinnate reticulate venation and prominent lateral veins. Both leaflet surfaces are glabrous. The leaflets are $3-4 \mathrm{~cm}$ in length for young leaves and 1.5-3.5 for old ones and $1-1.5 \mathrm{~cm}$ in width for both types. Leaflets have a faint odor and bitter taste.
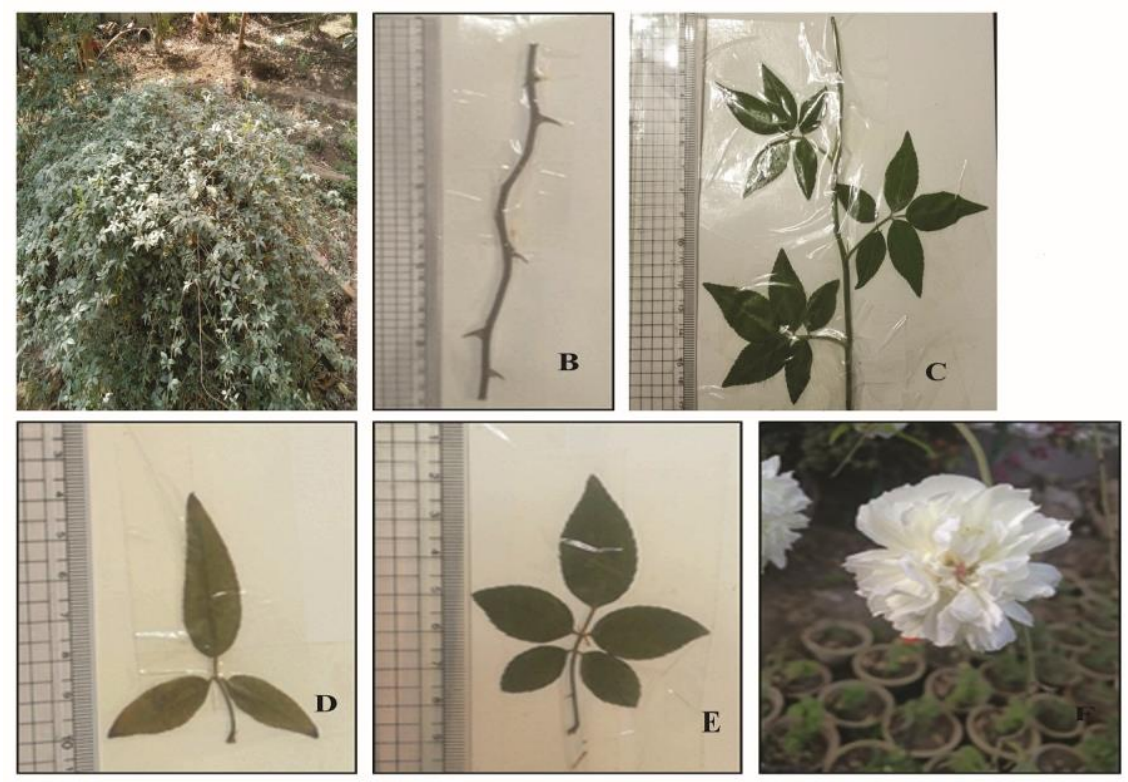

Fig. 1. Macromorpholgy of $R$. banksiae var. banksiae Ait. (RBW)

A: RBW herb, B: stem, C: stem with leaves, D: young leaf, E: old leaf, F: flower.

\subsection{Macromorphological characteristics of $R$.} polyantha "orange fairy" (RPO) (Fig. 2 A-E)

RPO is a small shrub (Fig. 2 A) that varies in height according to habitat. It blooms orange firecolored flowers either solitary or in clusters of three flowers on the branches. Morphologically, it differs from RBW where: Stem (Fig. 2 C) is shorter in length up to $1 \mathrm{~m}$ (with slightly wider diameter $0.6 \mathrm{~cm}$ ) with shorter internodes 1-1.5 $\mathrm{cm}$ long and it possesses greenish-brown color with a reddish tinge. Stems carry spines about $0.8-1 \mathrm{~cm}$ in length. The stem breaks easily exposing the inner pale yellow surface and projecting fibers. Stems are odorless with a bitter taste and sympodial branching. Leaves are alternate in phyllotaxis. The leaves (Fig. 2 D) are also compound imparipinnate with five leaflets on the rachis with a larger apical one. Leaflets are ovate in shape, 2 to $3.5 \mathrm{~cm}$ in length, and 1 to 2 $\mathrm{cm}$ in width with reddish color on their margin. Leaf petiole is winged with an enlarged base due to the adnation of its base to the stem. Flowers (Fig. 2 E) are orange in color with a faint odor and bloom during April-May. 
3.3. Macromorphological characteristics of $R$. polyantha "white fairy" (RPW) (Fig. 3 A-E)

RPW is an evergreen climbing rose (Fig. 3 A). It has the same morphological characteristics as RBW except for Stem (Fig. 3 B) is about $1 \mathrm{~cm}$ in diameter and reaching 2-3 $\mathrm{m}$ in length carrying strong spines about $2 \mathrm{~cm}$ in length. RPW spines are the longest and sharpest compared to RBW and RPO. Stem internodes are 3-5 $\mathrm{cm}$ in length (Fig. 3 C). RPW stem is hard to break with fibrous fracture and inner pale yellow color. Stems are odorless with a bitter taste and sympodial branching. Leaves are arranged alternately on the stem (Fig. 3 B) and their petiole bases show the adnation phenomenon. Leaf petiole is cylindrical in shape with a winged base (Fig. 3D). Leaves (Fig. 3D) are compound, imparipinnate with 5 or 7 leaflets, leaflets are small in size and becoming larger towards the top of the leaf. Leaflets are ovate to obovate in shape with a slight reddish margin, measuring 2 to 4.5 $\mathrm{cm}$ in length and 1 to $2 \mathrm{~cm}$ in width. Flowers (fig. $3 \mathrm{E})$ are white in color, solitary, or in clusters of three. Flowers have a characteristic aromatic odor. Flowers bloom heavily and repeatedly during April-May.
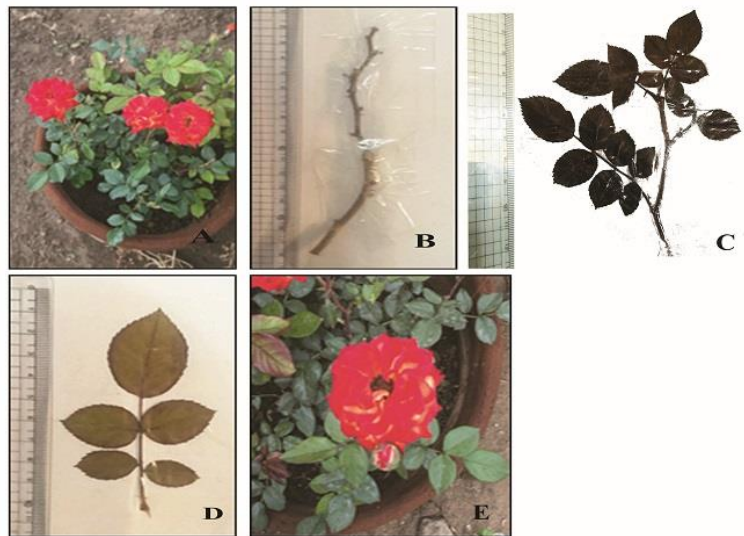

Fig. 2. Macromorpholgy of $R$. polyantha 'orange fairy' (RPO) A: RPO herb, B: stem, C: stem with leaves, D: leaf, E: flower
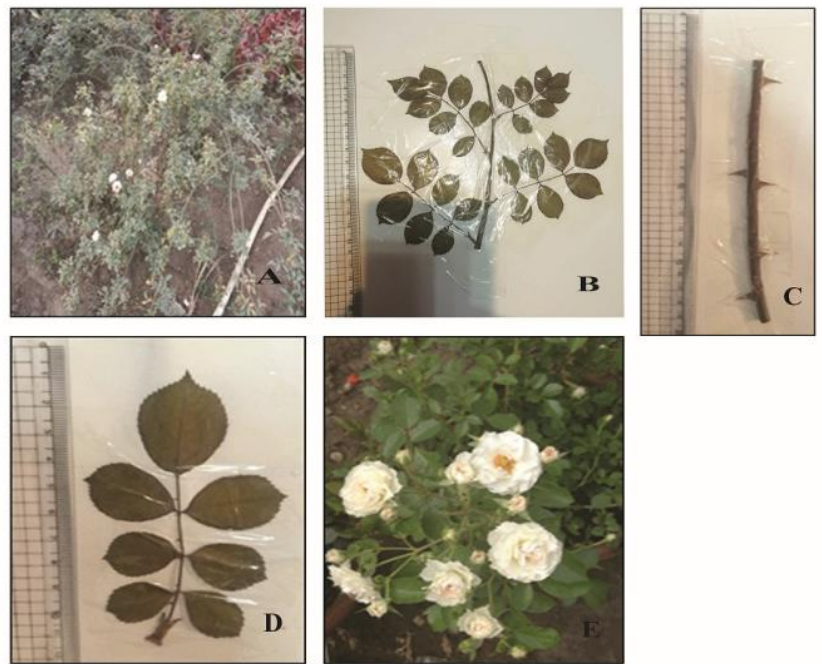

Fig. 3. Macromorpholgy of $R$. polyantha 'white fairy' (RPW) A: RPW herb, B: stem with leaves, C: stem, D: leaf, E: flower 


\subsection{Micromorphological characteristics of RBW}

\subsubsection{The Stem (Fig. 4)}

A transverse section in the young stem is rounded in outline. It is formed of epidermal cells covered with thick cuticles. Cortex is formed of different zones of collenchyma, collenchyma cells with reddish-brown content then parenchymatous cells with a distinct layer of endodermis. The pericycle consists of parenchymatous cells, containing prisms of calcium oxalate, traversed by lignified fibers in dome shapes. The vascular tissue is radially arranged, $1 / 4$ of the diameter, and is traversed by uniseriate medullary rays. Wide pith, $2 / 3$ of the diameter, is formed of two types of parenchymal cells that are arranged in characteristic groups where 3-4 large parenchymatous cells are surrounded by 5-7 smaller lignified parenchymatous cells forming a repeated pattern.
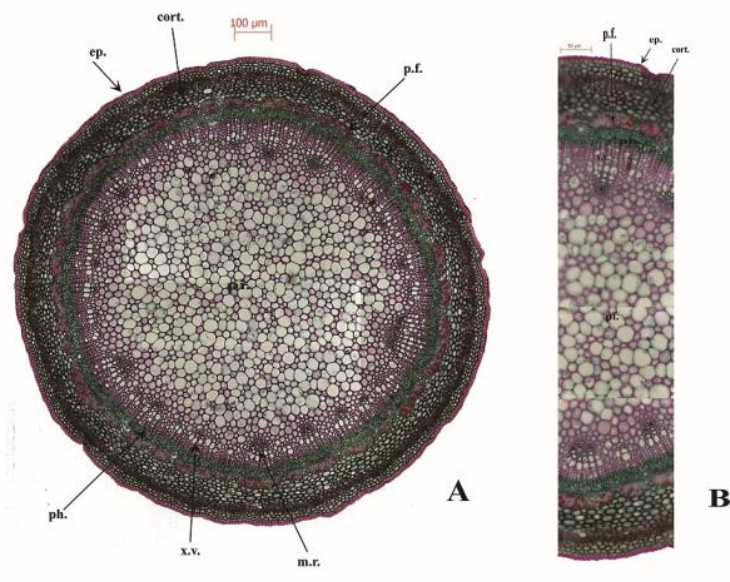

Fig. 4. Micromorphology of RBW stem A: T.S. in stem in low power $(X=100)$ B: T.S. in stem in high power $(X=400)$ ep., epidermis, p.f., pericycle fiber, x.v., xylem vessel, cort., cortex, ph., phloem, pi., pith

The epidermis: consists of polygonal cells, axially elongated with straight anticlinal walls and covered with a smooth cuticle. No stomata are present. Some epidermal cells contain mucilage and stained red with ruthenium red.

The cortex: is formed of three zones of cells; 2-3 rows of rounded collenchyma cells followed by 2-3 rows of rounded collenchyma cells with reddish-brown content giving them marble appearance then 4-5 rows of polygonal thinwalled parenchymatous cells. The endodermis is formed of a distinct layer with square or rectangular cells.

The pericycle: is formed of 2-3 rows of parenchymatous cells which contain prisms of calcium oxalate and are interrupted with lignified fibers. The pericyclic fibers are arranged in bundles, they have a narrow lumen and blunt apices.

The vascular tissue: is formed of a complete ring of the collateral vascular bundle and traversed by uniseriate medullary rays.

The phloem: The phloem region is traversed by uniseriate medullary rays consisting of thinwalled radially elongated cells.

The xylem: is composed of a continuous ring of secondary elements; lignified vessels, vessel segments, fibers, wood parenchyma and is traversed by uniseriate pitted medullary rays. The vessels are arranged in radial rows with spiral, annular, reticulate, and pitted thickenings. The vessel segments are pitted and reticulate thickening. The wood fibers are abundant, usually scattered in small groups with wide lumina, shorter than those of cortical fibers. The wood parenchyma is formed of elongated cells with pitted walls.

The pith: is wide, pith cells are of two types of parenchymatous cells; large parenchymatous cells usually 3-4 in number grouped and surrounded by 5-7 smaller lignified parenchymatous cells forming together a characteristic repeated pattern in the whole pith area (Fig. 4 B). 


\subsubsection{The Leaf (Fig. 5, 6)}

A transverse section in the young leaflet (Fig. 5) shows upper and lower epidermises enclosing dorsiventral mesophyll. The collenchyma layer appears beneath the upper epidermis in the midrib region. The palisade present in two rows and is discontinued over the midrib region. The midrib region is prominent on the lower side showing one crescent-shaped collateral vascular bundle accompanied by a pericycle formed of fibers.

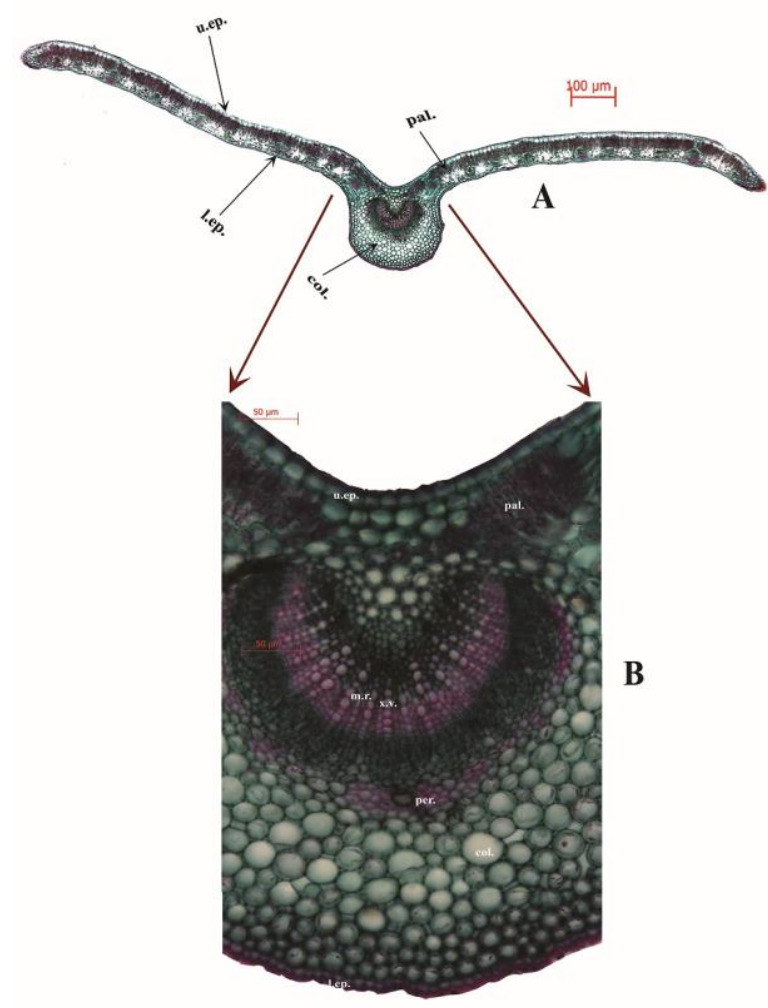

Fig. 5. Micromorphology of RBW young leaflet A: entire young leaflet T.S. in low power $(X=100)$ $\mathrm{B}$ : midrib area of the young leaflet in high power $(X=400)$ u.ep., upper epidermis, 1.ep., lower epidermis, pal., palisade, col., collenchyma, m.r., medullary rays, ph., phloem, per., pericycle, x.v., xylem vessel

The Epidermis: epidermal cells of both upper and lower surfaces are formed of polygonal thickened parenchymatous cells, isodiametric in shape showing beaded wavy anticlinal walls.
They are covered by thick cuticles. Stomata are found only on the lower epidermis; anomocytic with 4 to 7 subsidiary cells. Upper epidermal cells contain yellow content. Lower epidermal cells contain reddish-brown content and some of its cells show prisms and clusters of calcium oxalate. Some oil cells are present in the lower epidermis. Epidermal cells of both upper and lower epidermises are full of acidic mucilage.

The Mesophyll: is dorsiventral, formed of two rows of palisade cells, and is discontinued over the midrib region. The palisade layer is formed of elongated thin-walled cells with narrow intercellular spaces. Cells of the upper palisade layer are taller than the lower ones. Spongy tissue is composed of many rows of rounded parenchymatous cells with wide intercellular spaces.

The Midrib: the cortical tissue consists of 4-5 rows of collenchyma cells abutting the upper and lower epidermises followed by few rows of parenchyma. The parenchymatous cells are thinwalled, rounded, or oval with narrow intercellular spaces. The endodermis is indistinct. The pericycle is formed of an incomplete arch of fibers accompanied with parenchymatous cells containing prisms of calcium oxalate. The pericyclic fibers are surrounding the vascular tissue from below and are discontinued from above (Fig. 5 B). The vascular tissue is wide representing $1 / 3$ of the diameter, arch-shaped collateral vascular bundle with lower phloem separated from the xylem by cambium and traversed by uniseriate medullary ray. The phloem tissue is formed of soft phloem elements and traversed by uniseriate medullary rays, consisting of thin-walled isodiametric cells. The xylem is formed of lignified vessels showing spiral and annular thickenings together with fibers and wood parenchyma. Wood fibers are present accompanied with parenchymatous cells containing prisms of calcium oxalate forming 
crystal sheath. Wood parenchyma has a thick pitted wall.

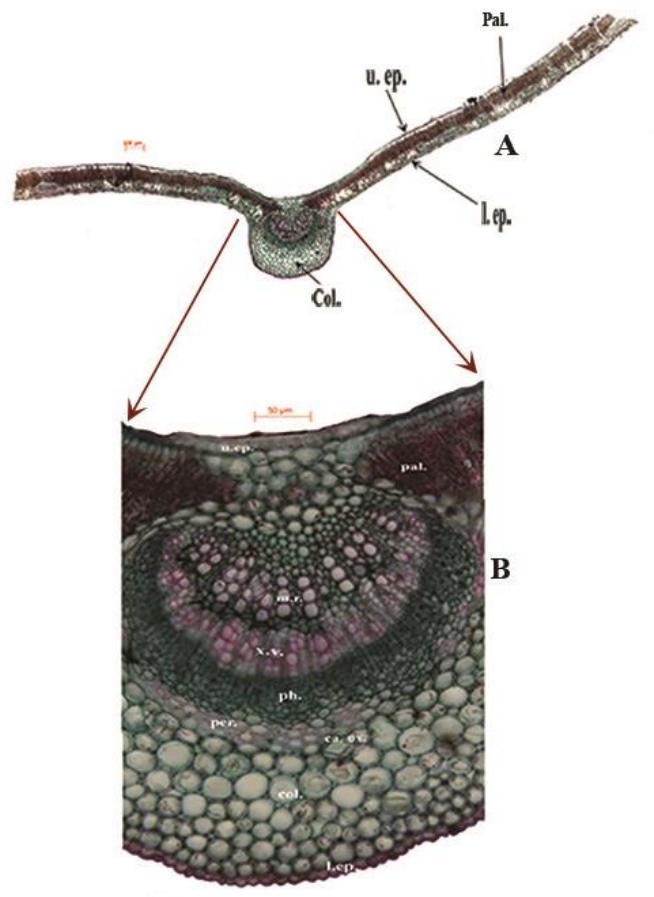

Fig. 6. Micromorphology of RBW old leaflet A: entire old leaflet T.S. in low power $(X=100)$ B: midrib area of the old leaflet in high power $(X=400)$ u.ep., upper epidermis, 1.ep., lower epidermis, pal., palisade, col., collenchyma, m.r., medullary rays, ph., phloem, per., pericycle, x.v., xylem vessel

A transverse section in the old leaflets (Fig. 6) is nearly similar to young ones except:

The vascular bundle is more developed taking concave-convex shape (kidney-shaped) rather than arch shape in young leaflets and xylem vessels are wider. Accumulation of calcium oxalate prisms and rosettes in mesophyll part.

\subsection{Micromorphological characteristics of RPO stem and leaflets (Fig. 7, 8)}

The microscopical characters of RPO are quite similar to RBW except for:

RPO stem is similar to what was previously discussed under RBW stem except epidermal cells are polygonal in shape with thick walls and contain brown content. The cortex is formed also of the same three zones discussed under RBW but in RPO cells are more flattened and compressed. The parenchyma of the cortex show scattered clusters of calcium oxalate. Pericyclic fibers are forming scattered bundles surrounding the vascular tissue and are flattened compared to the dome-shaped pericycle in RBW. A characteristic feature is the presence of lignified parenchymatous cells in the pith region that are spindle-shaped cells with a pitted surface (pitted parenchyma). The pith cells here are almost equal in size and are larger than those of RBW and they are not thickened (Fig. 7 B).

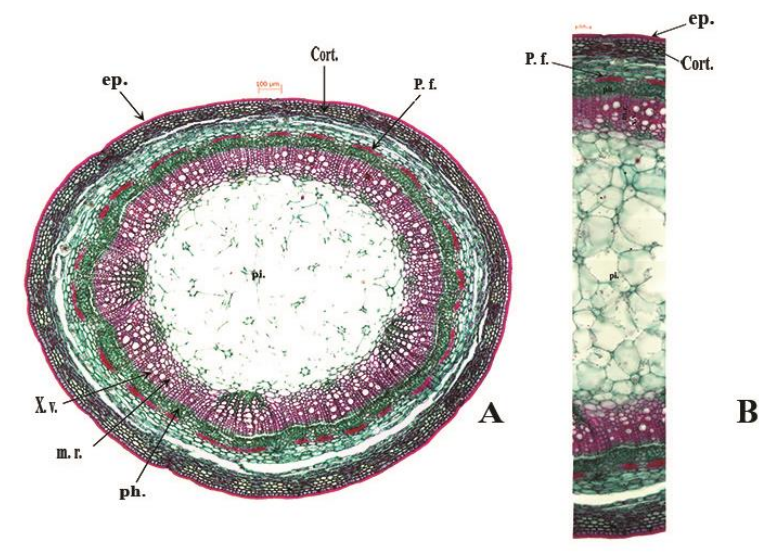

Fig. 7. Micromorphology of RPO stem

A: T.S. in stem in low power $(X=100)$

B: T.S. in stem in high power $(X=400)$

ep., epidermis, p.f., pericycle fiber, x.v., xylem vessel, cort., cortex, ph., phloem, pi., pith

In the RPO leaflet, both upper and lower epidermises are polygonal in shape and with straight anticlinal walls for the upper epidermal cells and beaded anticlinal walls for the lower one. Lower epidermis show reddish-brown colored content and anomocytic stomata with four subsidiary cells. Both prisms and clusters of calcium oxalate are found in the lower epidermis together with oil droplets inside the oil cell. Calcium oxalate rosettes accumulate in both upper and lower epidermises. Pericyclic fibers are less prominent and surrounding only the lower part of the vascular tissue. Lignified 
pericyclic fibers accompanied by parenchymatous cells containing prisms of calcium oxalate from crystal sheath. Individual fibers are elongated with narrow lumen and tapering ends. The vascular bundle is taking a concave-convex shape.

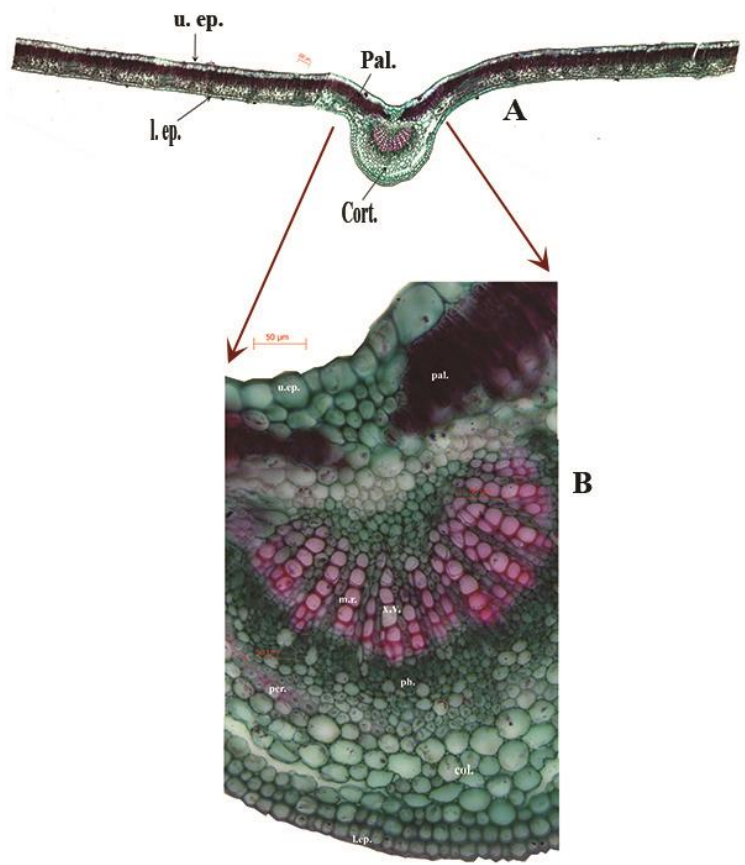

Fig. 8. Micromorphology of RPO leaflet

A: entire leaflet T.S. in low power $(X=100)$

B: midrib area of the leaflet in high power $(X=400)$

u.ep., upper epidermis, l.ep., lower epidermis, pal., palisade, col., collenchyma, m.r., medullary rays, ph., phloem, per., pericycle, x.v., xylem vessel

\subsection{Micromorphological characteristics of RPW stem and leaflets (Fig. 9, 10)}

The stem is as discussed before under RBW except Epidermal cells are polygonal with thick wall and brown content. The cortex shows characteristic large lignified parenchymal cells containing clusters of calcium oxalate. Pith cells are parenchymatous cells that are unequal in size and are not lignified, unlike RBW. Pith cells are forming a characteristic pattern or arrangement where one central small cell is surrounded by four larger cells.

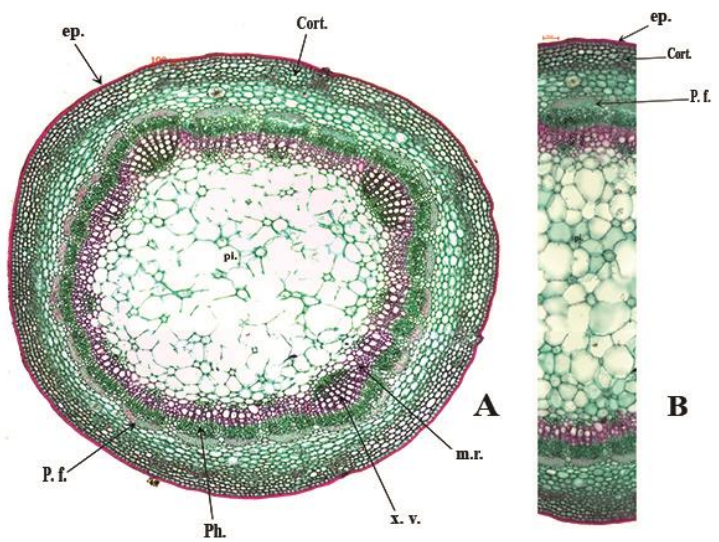

Fig. 9. Micromorphology of RPW stem A: T.S. in stem in low power $(X=100)$ B: T.S. in stem in high power $(X=400)$ ep., epidermis, p.f., pericycle fiber, x.v., xylem vessel, cort., cortex, ph., phloem, pi., pith

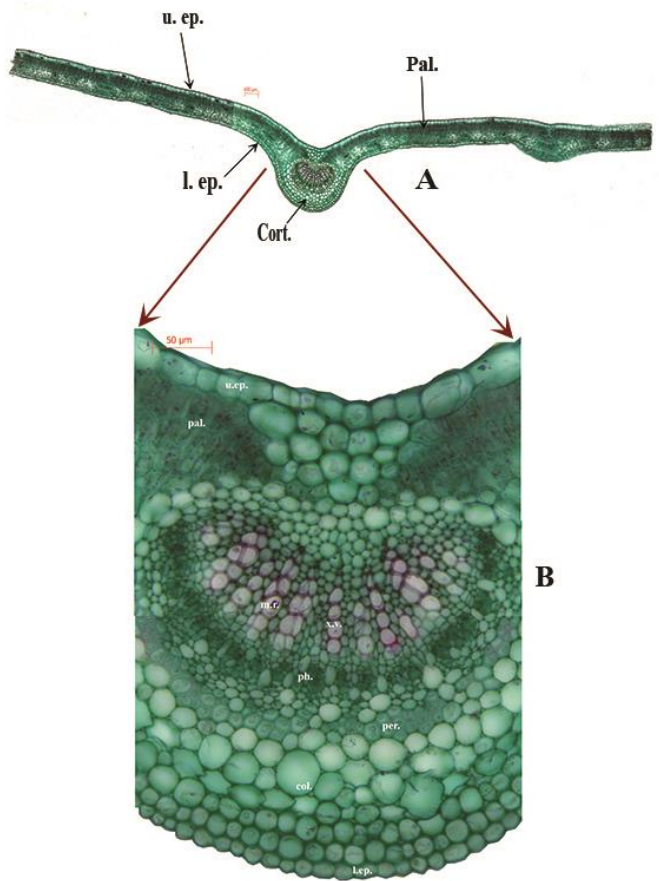

Fig. 10. Micromorphology of RPW leaflet A: entire leaflet T.S. in low power $(X=100)$ B: midrib area of the leaflet in high power $(X=400)$ u.ep., upper epidermis, l.ep., lower epidermis, pal., palisade, col., collenchyma, m.r., medullary rays, ph., phloem, per., pericycle, x.v., xylem vessel

RPW leaflet is similar to what was discussed under RBW leaf except for the upper epidermis 
shows brown content. The anticlinal walls of the upper epidermal cells are straight while those for the lower epidermis are with wavy anticlinal walls. Stomata are only seen in the lower epidermis, are of anomocytic type with five subsidiary cells. Both upper and lower epidermises are covered with a thin cuticle. Pericyclic fibers are less prominent and surrounding the lower part of the vascular tissue. The vascular bundle is taking a concave-convex shape.

Measurements of both leaves and stems of the three varieties were recorded in Table 1.

\subsection{Powdered RBW Stem and leaves (Fig. 11, 12) (Table.1)}

The powdered stem shows fragments of epidermal cells that are polygonal in shape covered with thick smooth cuticle with overlaying cork cells in top view (Fig. 11 A \& B). Pericyclic fibers in the form of crystal sheath with prisms of calcium oxalate. Fibers are of the narrow lumen and with blunt apices (Fig. 11 C). Different forms of xylem vessels viz. spiral and annular (Fig. 11 D).

The powdered leaflets are characterized by the presence of fragments of upper epidermal cells which are polygonal with a beaded wavy anticlinal wall (Fig. 12 A). They contain yellow content with no stomata (Fig. 12 B). Fragments of lower epidermal cells are also polygonal with beaded wavy anticlinal wall and scattered normocytic stomata with 4-7 subsidiary cells (Fig. 12 C). They contain reddish-brown content. Some of them show clusters and prisms of calcium oxalate. Oil cells from the epidermal layer are also present together with numerous scattered elongated palisade cells. Fragments of pericyclic fibers from the midrib region in the form of crystal sheath (Fig. 12 D). Fibers are elongated with a narrow lumen and blunt apices (Fig. 12 E).

\subsection{Powdered RPO stem and leaves (Fig. 13)} (Table.1)

The powdered stem shows fragments of epidermal cells that are polygonal in shape with thick walls and brown content (Fig. 13 A). Parenchymal cells from the cortex containing clusters of calcium oxalate. Lignified pitted parenchymatous cells from the pith region (Fig. 13 B).

The powdered leaflets are characterized by fragments of upper epidermal cells which are polygonal in shape with a straight anticlinal wall (Fig. 13 C). Fragments of lower epidermal cells with reddish-brown content. They are polygonally elongated, beaded anticlinal wall, and normocytic stomata with 4 subsidiary cells. Some cells contain clusters and prisms of calcium oxalate (Fig. 13 D, E \& F). Pericyclic fibers which are elongated with tapering ends and narrow lumen are present. Lignified fibers accompanied by parenchymatous cells containing prisms of calcium oxalate forming crystal sheath (Fig. 13 F).

\subsection{Powdered RPW stem and leaves (Fig. 14) (Table.1)}

The powdered stem shows fragments of epidermal cells that are polygonal in shape with thickened walls and brown content (Fig. 14 A). Large parenchymal cells of the cortex with clusters of calcium oxalate.

The powdered leaflets show fragments of upper and lower epidermal cells that are polygonal in shape and covered with a thin cuticle (Fig. 14 B \& C). The upper epidermis shows straight anticlinal walls and brown content. Lower epidermal cells show wavy anticlinal walls and anomocytic stomata with five subsidiary cells. Fragments of lignified pericyclic fibers accompanied by parenchymatous cells containing prisms of calcium oxalate as crystal sheath (Fig. 14 D \& E). 
Table 1. Microscopical measurements for different organs of RBW, RPO and RPW (in mm)

\begin{tabular}{|c|c|c|c|c|c|c|c|c|c|c|c|c|}
\hline \multirow{2}{*}{$\begin{array}{l}\text { Plant Name } \\
\text { Item }\end{array}$} & \multicolumn{3}{|c|}{ RBW } & \multirow[b]{2}{*}{ D } & \multicolumn{4}{|c|}{ RPO } & \multicolumn{4}{|c|}{ RPW } \\
\hline & $\mathbf{L}$ & W & $\mathbf{H}$ & & $\mathbf{L}$ & $\mathbf{W}$ & $\mathbf{H}$ & D & $\mathbf{L}$ & $\mathbf{W}$ & $\mathbf{H}$ & D \\
\hline \multicolumn{13}{|l|}{ Stem } \\
\hline Epidermis & $0.010-0.020$ & $0.025-0.005$ & & & $0.030-0.040$ & $0.010-0.020$ & & & $0.019-0.023$ & $0.012-0.015$ & & \\
\hline Pericyclic fiber & $0.980-1.00$ & $0.260-0.280$ & & & $1.040-1.080$ & $0.060-0.120$ & & & $0.980-1.000$ & $0.022-0.033$ & & \\
\hline Collenchyma & & & & $0.026-0.036$ & & & & & & & & \\
\hline Xylem vessels & $0.100-0.110$ & $0.010-0.020$ & & & & & & & & & & \\
\hline Wood fibers & $0.020-0.022$ & $0.004-0.006$ & & & & & & & & & & \\
\hline Ca. ox. prisms & - & - & & & $0.051-0.056$ & $0.015-0.021$ & & & & & & \\
\hline Ca. ox. clusters & - & - & & & & & & $0.062-0.069$ & & & & \\
\hline Pitted parenchyma & & & & $0.031-0.038$ & & & & $0.046-0.054$ & & & & \\
\hline \multicolumn{13}{|l|}{ Leaflet } \\
\hline Upper epidermis & $0.023-0.044$ & $0.008-0.015$ & & & & & & $0.024-0.040$ & & & & $0.038-0.046$ \\
\hline Lower epidermis & $0.015-0.025$ & $0.005-0.010$ & & & $0.041-0.051$ & $0.031-0.036$ & & $0.065-0.073$ & - & - & & $0.038-0.046$ \\
\hline Palisade & 0.044-0.048 & 0.004-0.008 & & & $0.033-0.036$ & $0.004-0.007$ & & & - & - & & - \\
\hline Stomata & $0.020-0.022$ & $0.013-0.018$ & & & $0.036-0.062$ & $0.026-0.031$ & & $0.023-0.031$ & $0.028-0.030$ & $0.020-0.023$ & & - \\
\hline Oil cell (l. ep.) & - & - & & $0.077-0.096$ & - & - & - & $0.02-0.03$ & - & - & - & - \\
\hline \multicolumn{13}{|l|}{ Ca. ox. rosettes } \\
\hline u.ep. & & & & & & & & $0.010-0.014$ & & & & \\
\hline 1. ep. & & & & & & & & $0.023-0.025$ & & & & \\
\hline Ca. ox. prism & - & - & & & $0.032-0.024$ & $0.008-0.016$ & 0.008 & & $0.15-0.17$ & 0.007-0.009 & & \\
\hline Ca. ox. cluster & - & - & & & & & & & & & & \\
\hline u. ep. & & & & & & & & $0.026-0.030$ & & & & \\
\hline 1. ep. & & & & & & & & $0.020-0.030$ & & & & \\
\hline Xylem vessels & $0.050-0.063$ & $0.003-0.008$ & & - & - & - & - & - & - & - & - & - \\
\hline Pericyclic fiber & $1.180-1.200$ & $0.048-0.056$ & & - & - & $1.27-1.30$ & $0.080-0.100$ & - & - & - & - & - \\
\hline
\end{tabular}

*L: Length, H: Height, W: Width, D: Diameter, (-) not found 

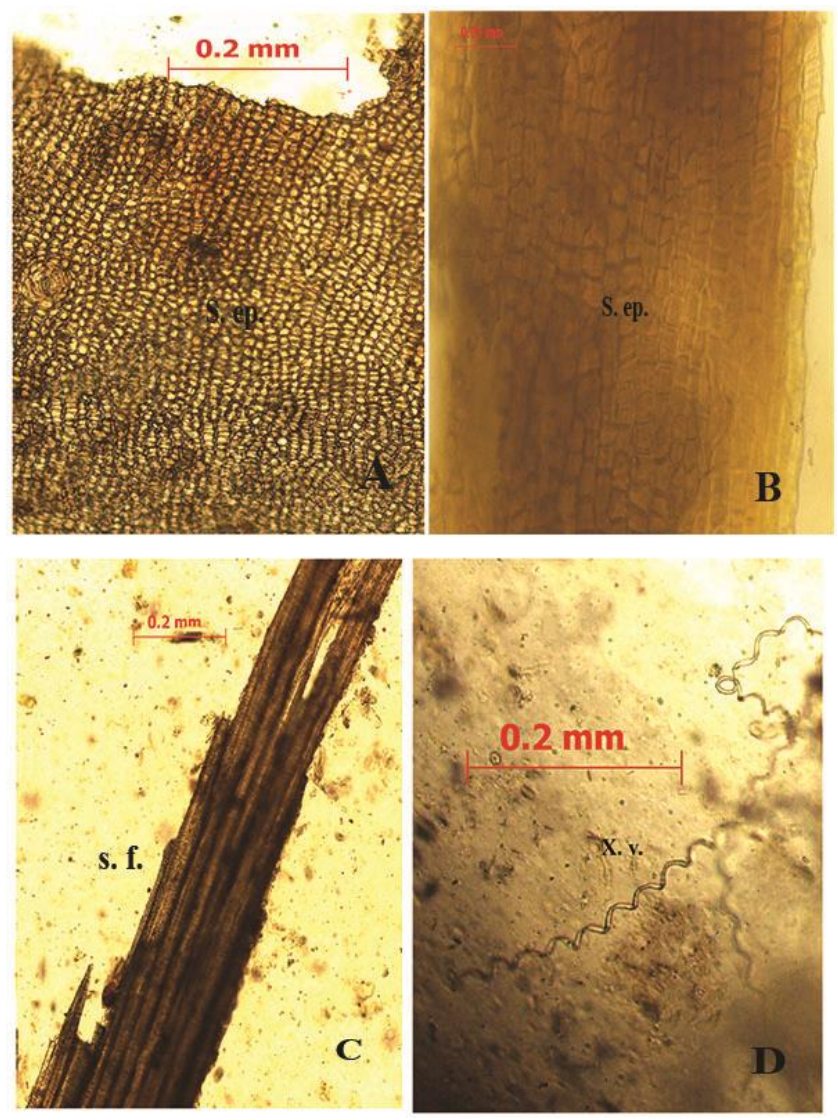

Fig. 11. Powdered elements of RBW stem

S. ep.: stem epidermis, s. f.: stem fiber, X. v.: xylem vessel
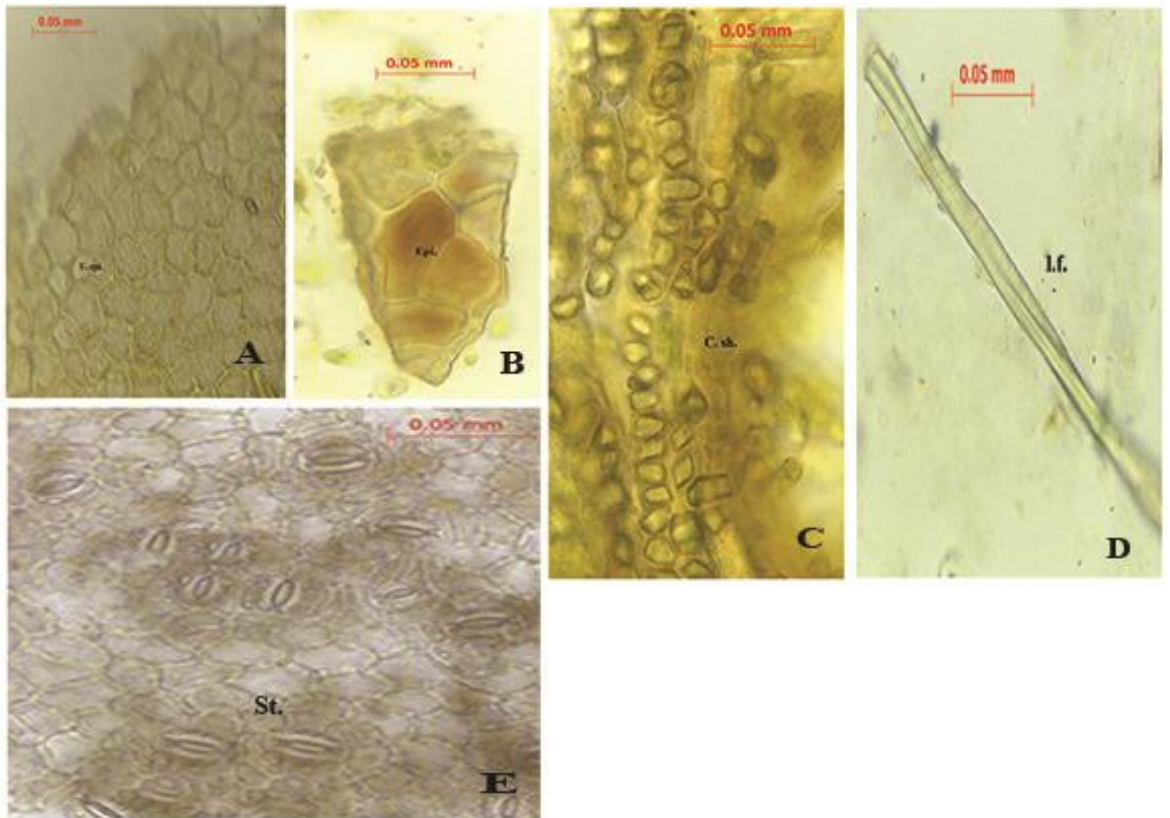

Fig. 12. Powdered elements of RBW leaf

U. ep.: upper epidermis, 1. f.: leaf fiber, C. sh.: crystal sheath 

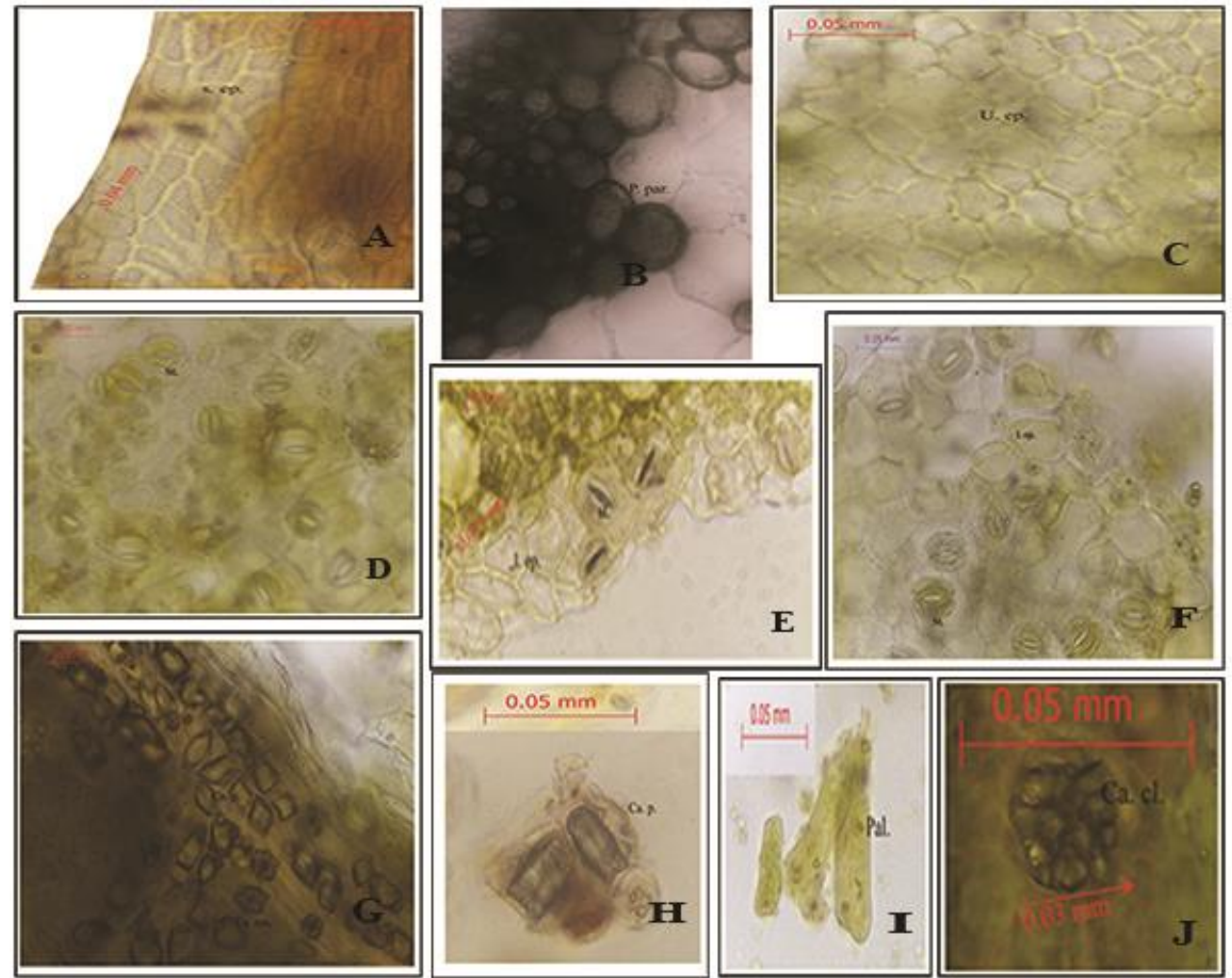

Fig. 13. Powdered elements of RPO stem and leaf

Ca. p.: calcium oxalate prism, 1. ep.: lower epidermis, st.: stomata, U. ep.: upper epidermis, Pal.: palisade, Ca. Cl.: calcium oxalate cluster, s. ep.: stem epidermis, P. par.: pitted parenchyma
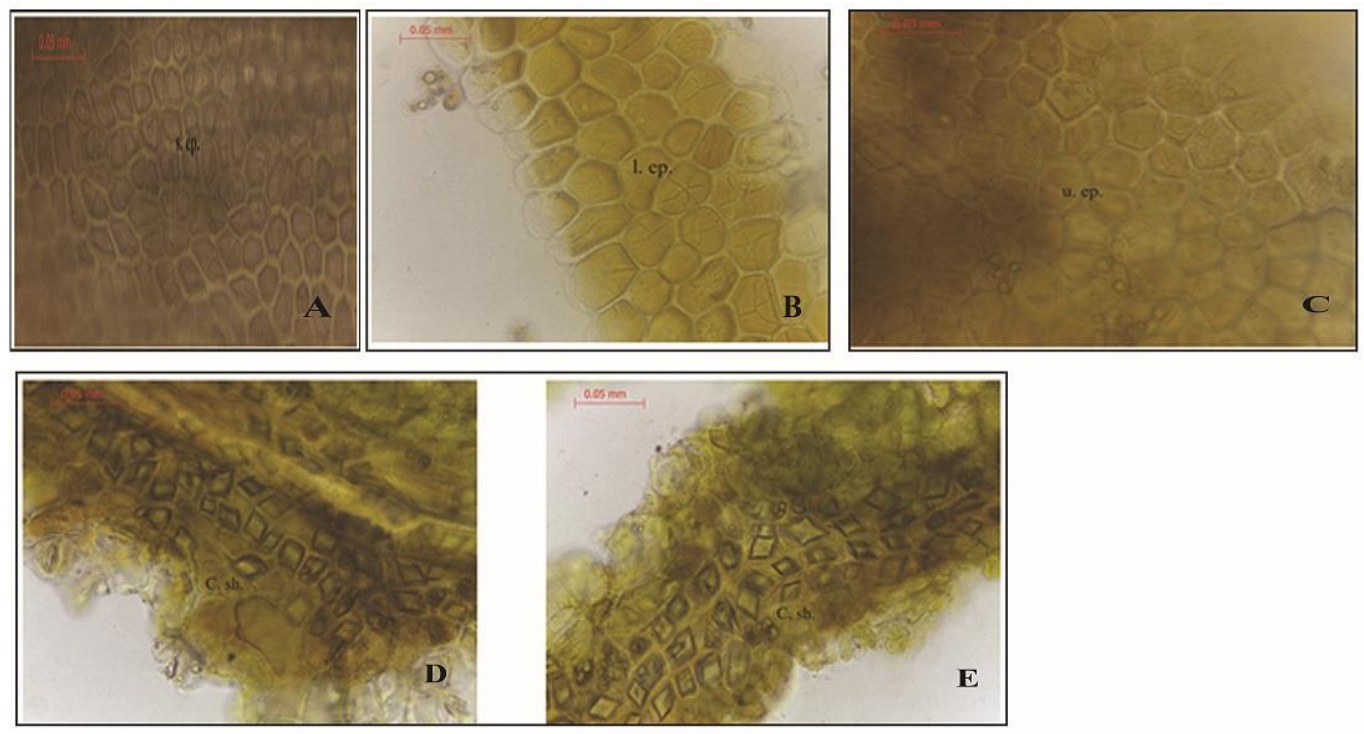

Fig. 14. Powdered elements of RPW stem and leaf

u. ep.: upper epidermis, l. ep.: lower epidermis, C. sh.: crystal sheath, s.ep.: stem epidermis 


\subsection{DNA profiling using Random Amplified Polymorphic-DNA Polymerase Chain Reaction Technique (RAPD-PCR)}

DNA profiling is one of the cornerstones of today's plant science, being one of the advanced and reliable tools for plant characterization and differentiation. It applies the use of different markers to study the specific plant genetic buildup [20]. RAPD essay is one of the most popular DNA profiling techniques which relies on the use of PCR and a series of short oligonucleotide primers that shine at a certain sequence of the tested DNA leading to characteristic pattern for each plant genome and help in producing a reliable fingerprint for each plant [21].

To detect the genetic diversity of the three Rosa varieties, their DNA was extracted and amplified using thirteen decamer primers. The thirteen markers successfully directed the amplification of a genomic-specific fingerprinting for the extracted DNA fragments. The primers used carried the codes; (OP-P-01, OP-P-02, OP-P-03, OP-P-04, OP-P-06, OP-P-
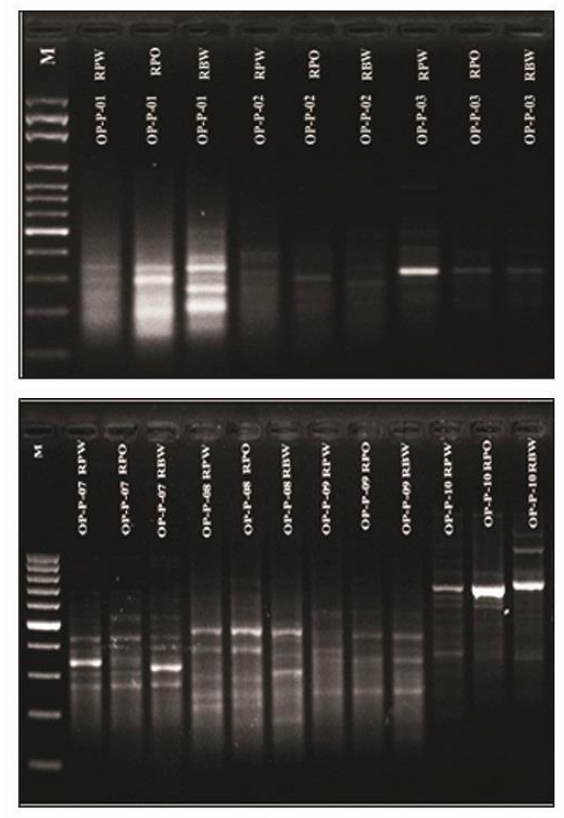

07, OP-P-08, OP-P-09, OP-P-10, OP-P-11, OPP-12, OP-P-13, and OP-P-14) had generated RAPD-PCR products shown in Fig. 15. The three varieties of RAPD-PCR products showed multiple profiles for the used DNA primers (fig. 15) where primers OP-P-8, OP-P-10, OP-P-11, OP-P-12, and OP-P-14 showed the highest degree of similarity between RPO and RPW and differentiated them from RBW.

Chemometric writes a new scenario for plant genomic characterization. Plant complicated genomic data can be processed through principal component analysis (PCA) and hierarchal clustering analysis (HCA) and differentiated into clusters representing their closeness or farness from their families, genera, and related species [22]. The hierarchal dendrogram for the RAPDPCR results (Fig. 16) further confirmed the closeness of RPO and RPW forming one cluster and separated them from RBW in another cluster. These results were following the morphological and microscopical characters discussed above for these three varieties.
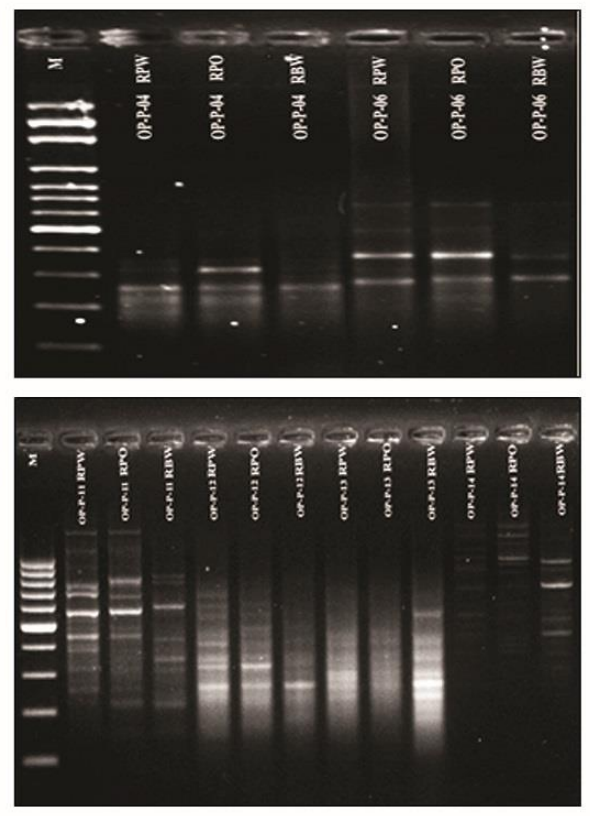

Fig. 15. RAPD-PCR products for RPW, RPO, and RBW RPW: $R$. polyantha Thunb. "white the fairy", RPO: Rosa polyantha Thunb."orange the fairy", RBW: R. banksiae var. banksiae Ait 


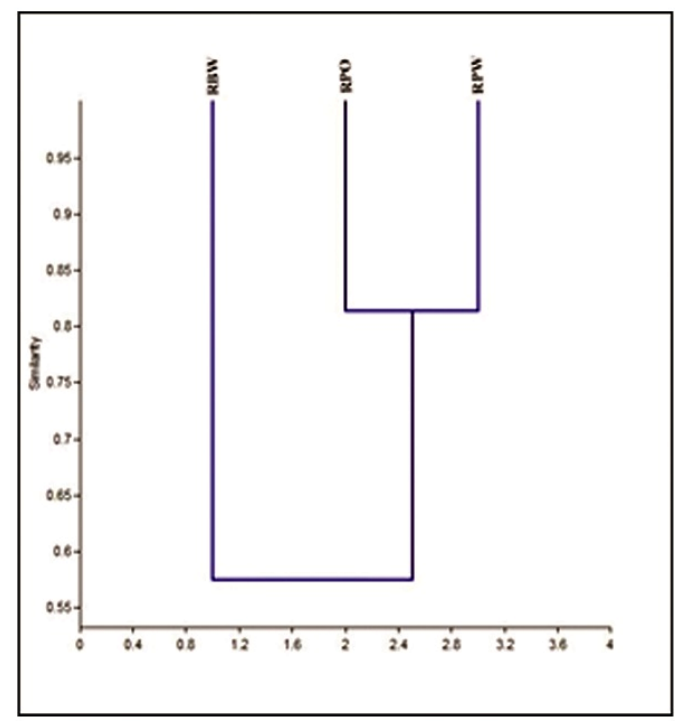

Fig. 16. Hierarchal cluster dendrogram for RPW, RPO, and RBW

RPW: R. polyantha Thunb. "white the fairy”, RPO: Rosa polyantha Thunb.“orange the fairy”, RBW: R. banksiae var. banksiae Ait

\section{DISCUSSION}

Plants occur in nature in different shapes and forms according to their habitat, genetic traits, climatic conditions, cultivars, and many other reasons $[\mathbf{2 3}, \mathbf{2 4}]$. Even plants occurring within the same species may differ in their morphological or genetic structure leading to new subspecies and varieties. The science of botany had contributed widely in differentiating different plant species according to their morphological traits and their microscopical characters but the main obstacle was the plants with complex taxonomy and interrelated species due to polyploidy and hybridization, either natural or artificial, like in the case of Rosaceae plants especially genus Rosa [17]. The need for a more specific way to further differentiate plants like those of Rosa was fulfilled by the profiling of their genetic content with the help of DNA assay methods like RAPD assay [21].

Macro- and microscopical characters of RBW, RPO, and RPW were investigated. Their features resemble the general characters of family Rosaceae members; they are evergreen climbing shrubs. Stems are green when young and brown when old. Leaves are compound. Flowers are in either solitary or in clusters, showy and heavily blooming. They carry a normocytic stoma on the lower epidermis of the leaf. Different forms of calcium oxalate as clusters and prisms are in different parts of the leaf and stem.

The three varieties of macro-and micromorphological characters carried a lot of similarities while their differences helped in their differentiation viz. stem shapes, color, and dimensions. Their leaflets differ in size and shape. Their flowers' colors where RBW and RPW are white and RPO is orange. Their powdered elements with their dimensions (Table 1) all helped in their characterization and differentiation.

When profiling their genetic contents using the RAPD-PCR assay, it was clear that five markers namely; OP-P-8, OP-P-10, OP-P-11, OP-P-12, and OP-P-14 successfully distinguished the three varieties which were clear in the PCR product (Fig. 15) and the hierarchical dendrogram (Fig. 16). The two polyantha roses 
showed close genetic content as they belong to the same species.

In this study, the two approaches (botanical and genetic) used in profiling roses had successfully differentiated the three Rosa varieties through their botanical and genetic traits which further emphasizes the big role played by the science of botany and DNA fingerprinting in differentiating plants of complex taxonomy.

\section{CONCLUSION}

It can be concluded that, by comparing the macro-and micromorphological characters of the back Asian rose and the two polyantha roses, it was clear that the polyantha roses were closely related to each other with nearly similar traits and some differences from the back Asian rose. All of the chosen plants share the common Rosaceae family characters as they belong to the same genus. They are all climbing shrubs with showy flowers, compound leaves, and spiny stems. RAPD assay further confirmed the botanical results where the common profiles of RPO and RPW placed them in one cluster on the hierarchal dendrogram while RBW appeared in another cluster.

\section{Declarations}

\section{Ethics approval and consent to participate}

Not applicable

\section{Consent to publish}

Not applicable

\section{Availability of data and materials}

The data generated or analyzed during this study all are included in the main manuscript.

\section{Conflict of interest}

The authors declare that there is no conflict of interest.

\section{Funding}

No funding source was received

\section{Authors' contributions}

Esraa A. Elhawary: captured the photos, writing the original draft. Dr. Nada M. Mostafa: supervision, manuscript reviewing \& editing. Prof. Rola M. Labib: supervision, manuscript reviewing \& editing. Prof. Abdel Nasser B. Singab: supervision, manuscript reviewing \& editing. All authors have read and approved the final manuscript.

\section{REFERENCES}

1. Xiang, Y., et al., Evolution of Rosaceae fruit types based on nuclear phylogeny in the context of geological times and genome duplication. Mol Biol Evol, 2017. 34(2): 262281.

2. Basu, S., et al., The genus Rosa: An aristocrat from the plant family with class, color, and fragrance. Iran Soc Environ, 2015. 1-9.

3. Khaleghi, A. and Khadivi, A., Morphological characterization of Damask rose (Rosax Damascena Herrm.) germplasm to select superior accessions. Genet Resour Crop Evol, 2020. 67: 1981-1997.

4. Zeng, C., et al., Phenolic composition, antioxidant and anticancer potentials of extracts from Rosa banksiae Ait. Flowers. Molecules, 2020. 25(13): 3068.

5. Zhang, J., Plantlist: looking up the status of plant scientific names based on the plant list database. R package version 0.5. 3, 2019.

6. Dadhwal, I., Genotypic evaluation of miniature, polyantha and floribunda roses (Rosa hybrida L.) for pot culture, 2016, Punjab Agric Uni, Ludhiana.

7. Li, S., et al., Flavonoids and triterpenoids from the roots of Rosa laevigata. J Mex Chem 
Soc, 2014. 58(4): 374-377.

8. Dong, D., et al., Protective effects of the total saponins from Rosa laevigata Michx. fruit against carbon tetrachloride-induced acute liver injury in mice. Food Chem Toxicol, 2015. 62: 120-30.

9. Tong, H., et al., Characterization of a polysaccharide from Rosa davurica and inhibitory activity against neutrophil migration. Int J Biol Macromol, 2016. 89: $111-7$.

10. Li, Y.K., et al., New isoprenylated aurones from the flowers of Rosa damascena. Helv Chim Acta, 2014. 97(3): 414-419.

11. Gorji-Chakespari, A., et al., Classification of essential oil composition in Rosa damascena Mill. genotypes using an electronic nose. J Appl Res Medic Aromat Plants, 2017. 27-34.

12. Czyzowska, A., et al., Polyphenols, vitamin C and antioxidant activity in wines from Rosa canina L. and Rosa rugosa Thunb. J Food Compos Anal, 2015. 39: 62-68.

13. Mahboubi, M., Rosa damascena is a holy ancient herb with novel applications. J Tradit Complement Med, 2016. 6(1): 10-16.

14. Yang, Y., et al., Tormentic acid inhibits IL1beta-induced inflammatory response in human osteoarthritic chondrocytes. Inflammation, 2016. 39(3): 1151-1159.

15. Esrafil Mansouri, A.H., Afzalzadeh, M. R., Zargar, A. A. and Meamar, Z., Combined effects of retinoic acid and hydro-alcoholic extract of Rosa damascena Mill. on the wound in diabetic rats. Iran J Pharma Res, 2016. 15(2): 8 .

16. Cunja, V., et al., Frost decreases the content of sugars, ascorbic acid, and some quercetin glycosides but stimulates selected carotenes in Rosa canina hips. J Plant Physiol, 2015. 178:
$55-63$.

17. Tomljenovic, N. and Pejić, I., Taxonomic Review of the genus Rosa. Agric Conspec Scientific, 2018. 83(2): 139-147.

18. Salarizadeh, S. and Kavousi, H.R., Application of random amplified polymorphic DNA (RAPD) to detect the genotoxic effect of cadmium on two Iranian ecotypes of cumin (Cuminum cyminum). J Cell Mol Res, 2015. 7(1): 38-46.

19. Milad, R., et al., Botanical and genetic characteristics of Eremophila maculata and Eremophila purpurascens (Scrophulariaceae). World J Pharm Res, 2013. 2: 2711-2736.

20. Muazu, L., Elangomathavan, R., and Ramesh, S., DNA fingerprinting and molecular marker development for Baliospermum montanum (Willd.) Muell. Arg. Int J Pharmacogn Phytochem Res 2016, 2016. 8(8): 1425-1431.

21. Kumar, N.S. and Gurusubramanian, G., Random amplified polymorphic DNA (RAPD) markers and its applications. Sci Vis, 2011. 11(3): 116-124.

22. Bystrzanowska, M. and Tobiszewski, M., Chemometrics for selection, prediction, and classification of sustainable solutions for green chemistry-A review. Symmetry, 2020. 12(12): 2055.

23. Mostafa, N.M., Antibacterial activity of ginger (Zingiber officinale) leaves essential oil nanoemulsion against the cariogenic Streptococcus mutans. J Appl Pharm Sci, 2018. 8(09): 034-041.

24. Ayoub, N., Singab, A.N., Mostafa, N., Schultze, W., Volatile constituents of leaves of Ficus carica Linn. grown in Egypt. J Essent Oil Bear Pl, 2010. 13(3): 316-321. 